\title{
TANTANGAN DAN HARAPAN BAHASA GALIK PADA ERA-MILENIAL
}

\section{CHALLENGE AND HOPE OF GALIK LANGUAGE IN MILENIAL ERA}

\author{
Martina \\ Balai Bahasa Kalimantan Barat \\ aan_martina@yahoo.com
}

\begin{abstract}
ABSTRAK
Era-milenial ini memberikan pengaruh besar pada kehidupan masyarakat. Ilmu pengetahuan dan teknologi berkembang pesat sehingga setiap orang berusaha memantaskan diri dengan perubahan dan kemajuan yang ada, termasuk adopsi bahasa. Terkait adopsi bahasa tersebut, masalah yang muncul adalah penutur bahasa daerah tertentu berpaling menggunakan bahasa lain ketika kembali ke daerah asalnya. Oleh karena itu, penelitian ini mendeskripsikan tantangan dan harapan bahasa Galik era-milenial. Metode yang digunakan adalah metode deskriptif dengan pendekatan kualitatif. Teknik pengambilan data dilakukan dengan observasi dan wawancara. Hasil penelitian menunjukkan bahwa tantangan yang dihadapi penutur bahasa Galik pada era-melenial berupa perubahan sikap berbahasa masyarakat dan kaum terpelajar setelah kembali ke kampung halamannya. Sikap berbahasa masyarakat dan kaum terpelajar Galik dipengaruhi oleh lingkungan dan pengetahuan dari luar, khususnya penggunaan bahasa. Bahasa yang digunakan sudah mengalami pergeseran ketika berkomunikasi dengan masyarakat di lingkungannya. Mereka memilih bahasa yang dianggap lebih modern dan bergengsi di dalam lingkungannya, yaitu bahasa Indonesia, Melayu, Jawa, Ribun, dan Inggris.
\end{abstract}

Kata kunci: tantangan, harapan, bahasa, Galik, era-milenial

\begin{abstract}
Millenial era has a major influence on people's lives. Science and technology is growing so rapidly, so that everyone tries to fit themselves with the existed changes and advances including the adoption of language. Regarding language adoption, the problem that arises now is that speakers of regional languages turn to use other languages when returning to their home areas. Therefore, this study highlights the challenges and expectations of Galik in the millennial era. The method used is the descriptive method with a qualitative approach. The data is collected by doing observation and interview. The collected data is then classified and analyzed according to the problem raised. The results of the study show that the challenges faced by speakers of Galik in these eras, namely the change of attitude of the educated speakers toward the language when returning to their hometowns. The language attitude of the community and Galik scholars in influenced by the environment and outside knowledge. The language used by the educated speakers has undergone a shift when communicating with people in their environment. They tend to use languages that considered more modern and
\end{abstract}


Tuah Talino

Tahun XIII Volume 13 Nomor 2 Edisi 6 Desember 2019

ISSN 0216-079X E-ISSN 2685-3043

Balai Bahasa Kalimantan Barat

prestigious in their environment, namely Indonesian, Malay, Javanese, Ribun, and English.

Keywords: challenges, expectations, language, Galik, millennial era

\section{PENDAHULUAN}

Istilah generasi milenial memang sedang akrab terdengar saat ini. Generasi milenial atau sering juga disebut millennials merupakan sebuah istilah yang popular untuk menggantikan istilah generasi Y (GenY). Generasi Y adalah cohort (kelompok demografis) yang lahir setelah generasi $\mathrm{X}$ (yang umum disebut ABG, Angkatan Bapak Gue). Menurut para peneliti sosial, generasi Y atau millennials ini lahir pada rentang tahun 1980-an hingga 2000. Dengan kata lain, generasi millennial ini adalah anak-anak muda yang saat ini berusia antara 15-35 tahun. Kata millennials diciptakan oleh dua pakar sejarah dan penulis Amerika, William Strauss, dan Neil Howe dalam beberapa bukunya menyebutkan bahwa millennial generation atau generasi $\mathrm{Y}$ juga akrab disebut dengan generation me atau echo boomers. https://www.kominfo.go.id/content/detail/8566/mengenal-generasimillennial/0/sorotan_media.

Generasi era-milenial akhir-akhir ini banyak diperbincangkan, mulai dari pendidikan, moral, budaya, etika kerja, ketahanan mental, sampai dengan penggunaan teknologi. Penyebabnya adalah generasi milenial sangat jauh berbeda dari generasi $\mathrm{X}$ dan baby boomer. Perbedaan kedua era itu sangat mencolok terutama pandangan dan perilaku mereka. Generasi $\mathrm{x}$ dan baby boomer dalam pemanfaatkan teknologi sangat bijaksana. Kemajuan teknologi dimanfaatkan secara benar dan disesuaikan dengan kondisi yang ada. Namun di era-milenial ini, kecenderungan generasi muda terlena dengan kemajuan teknologi tanpa memilahmilih yang cocok dan pantas untuk dilakukan. Para orang tua mulai kerepotan menghadapi sikap generasi ini karena gaya yang ditunjukkannya. Misalnya, menggunakan barang-barang terbaru yang memiliki nama terkenal. Ada anggapan bahwa generasi milenial ini dicap dengan stereotip (stereotype) yang sama, yaitu malas dan narsis. Menurut Suandi (2014: 45), stereotip adalah gambaran cerminan indikator karena tidak ada kaitannya dengan style-shifting. Jadi, sterotip tidak berhubungan dengan perbedaan-perbedaan konteks sosial, perbedaan lawan tutur, dan tujuan-tujuan personal.

Terkait era-milenial ini, setiap orang terkena dampaknya, baik ibu kota negara, ibu kota provinsi, kota/kabupaten maupun desa (kampung). Generasi milenial ini menunjukkan bahwa generasi milenial semakin terlena dengan perkembangan teknologi dan pengetahuan tanpa batas. Sumber informasi tanpa batas inilah yang dijadikan dasar generasi milenial saat ini untuk mengubah atau menghilangkan apa yang dimilikinya, misalnya penggunaan bahasa daerah. Adanya anggapan dari generasi milenial saat ini bahwa kebiasaan lama tidak perlu dipertahankan keberadaannya merupakan pemikiran yang keliru. Jika anggapan ini dipertahankan, banyak hal yang hidup dan berkembang di tengah-tengah kehidupan generasi ini akan hilang dengan sendirinya.

Pemikiran seperti itu disebabkan oleh berbagai hal diantaranya, faktor pendidikan dan lingkungan yang ada di sekelilingnya. Pendidikan yang mengarahkan seseorang untuk lebih banyak berinteraksi dengan orang lain dan 
Tuah Talino

Tahun XIII Volume 13 Nomor 2 Edisi 6 Desember 2019

ISSN 0216-079X E-ISSN 2685-3043

Balai Bahasa Kalimantan Barat

dunia luar. Para generasi muda dari berbagai pelosok desa dan kota berlombalomba melanjutkan pendidikannya ke ibukota provinsi atau ibu kota negara. Ketika mereka menimba ilmu, banyak hal yang diketahui, diperoleh dan langsung diterapkan dalam kehidupan mereka, termasuk bahasa.

Bahasa sebagai alat komunikasi manusia memegang penaranan penting dalam masyarakat. Sebagai alat komunikasi, bahasa menentukan cara seseorang berkomunikasi dan berinteraksi satu dengan yang lain di lingkungannya. Lingkungan yang ada di sekitar kita akan berterima dengan bahasa lingkungan tersebut. Maksudnya, seseorang yang menetap di lingkungan yang baru, harus menyesuaikan bahasa yang digunakan di lingkungan dimana dia menetap. Ketergantungan berbahasa tersebut sesuai dengan pernyataan Sumarsono (2013: 199) bahwa dalam situasi tertentu dua atau beberapa bahasa terlibat di dalamnya dan setiap warga menjadi dwibahasawan, baik aktif maupun pasif. Kondisi seperti inilah yang akan disoroti dan digali oleh peneliti terkait dengan tantangan dan harapan bahasa Galik pada era-milenial.

Bahasa Galik merupakan satu diantara bahasa daerah yang ada di Kalimantan. Hasil penelitian tim pemetaan Balai Bahasa Kalimantan Barat (2012) disebutkan bahwa bahasa Galik merupakan bahasa tersendiri di Kalimantan Barat dengan perbedaan bahasa dengan bahasa daerah lainnya di atas $85 \%$. Bahasa tersebut tersebar beberapa kawasan khususnya di Kecamatan Beduai Kabupaten Sanggau. Sampai saat ini, jumlah penutur bahasa Galik belum diketahui secara jelas. Meskipun bahasa Galik termasuk bahasa besar di Kalimantan Barat, penutur muda bahasa ini mengalami penurunan serius. Terbukti, penggunaan bahasa Galik kurang terlihat di ranah keluarga, masyarakat, dan sekolah. Bahasa Indonesia, asing, dan daerah lain lebih dominan dibandingkan dengan bahasa daerahnya sendiri.

Berkurangnya penggunaan bahasa Galik di kalangan genarasi milenial karena perkembangan teknologi yang begitu pesat. Bahasa Galik tidak lagi menjadi bahasa penghubung diantara mereka. Ada anggapan bahwa anak milenial harus mengunakan segala sesuatunya dari luar termasuk bahasa. Interaksi komunikasi tidak lagi menggunakan bahasa Galik sebagai bahasa penghubung daintara mereka. Hal inilah menjadi tantangan bagi penutur Galik di masa-masa akan datang. Tantangan bagaimana menyikasi perkembangan zaman tanpa melepaskan aset yang dimilikinya.

Masalah dalam penelitian ini dibagi menjadi dua, yaitu sebagai berikut. Pertama, bagaimanakah tantangan bahasa Galik pada era-milenial ini? Kedua, bagaimanakah harapan bahasa Galik pada era-milenial ini? Tujuannya adalah mendeskripsikan tantangan bahasa Galik di era-milenial. Kedua, mendeskripsikan harapan bahasa Galik pada era-milenial.

Penelitian tentang bahasa Galik pernah dilakukan oleh beberapa peneliti, diantaranya, penelitian dalam Jurnal Untan dengan judul "Nomina Bahasa Galik" yang dilakukan oleh Florentina dkk. Kajian ini menyimpulkan ciri nomina dalam bahasa Dayak Galik, yaitu dapat didahului kata depan di dan ke, dapat didahului kata bilangan, dapat diikuti kata ganti [ku?] 'ku', [mu?] 'mu', dan dapat diikuti oleh kata penunjuk ini dan itu. Dalam kalimat yang berpredikat verba, nomina cenderung menduduki fungsi subjek, objek, keterangan, dan pelengkap. Nomina 
Tuah Talino

Tahun XIII Volume 13 Nomor 2 Edisi 6 Desember 2019

ISSN 0216-079X E-ISSN 2685-3043

Balai Bahasa Kalimantan Barat

bahasa Galik ini tidak dapat diingkarkan dengan kata [kadu?] 'tidak', kata pengingkarnya [bvkvtn] 'bukan'. Selain itu, nomina pada umumnya dapat diikuti oleh adjektiva, baik secara langsung maupun diantarai kata $[d v]$ 'yang'. Secara umum, bentuk nomina bahasa Galik ada dua, yaitu nomina dasar dan nomina tuturan.

Selanjutnya, ada dua kajian yang dilakukan Martina (2018a) yang menyoroti fungsi bahasa Galik sebagai pengungkap budaya dan sebagai kearifan lokal pada Dayak Galik. Kajian pertama dengan judul "Bahasa Pengungkap Budaya Dayak Galik" menyimpulkan bahwa bahasa Galik bisa mengungkap Dayak Galik bagi generasi muda melalui nyanyian dan upacara penyambutan adat. Nyanyian dan tradisi penyambutan tamu merupakan upaya pelestarian dan pengembangan bahasa Galik dan penanaman nilai-nilai kearifan lokal yang ada di dalamnya.

Kajian kedua "Upaya Revitalisasi Bahasa Galik Menguatkan Pengetahuan Generasi Muda akan Nilai Kearifan Lokal”. Dalam kajiannya, Martina (2018b) menjelaskan bahwa kurangnya pengetahuan generasi muda tentang nilai-nilai kearifan lokal disebabkan beberapa faktor, yaitu sekolah tidak menyelenggarakan muatan lokal berbahasa Galik, keluarga pasif berbahasa daerah, dan masyarakat (generasi muda) memilih untuk menggunakan bahasa yang lebih modern. Kurangnya pembinaan dan pengembangan bahasa Galik, menunjang terperosoknya pengetahuan generasi muda akan nilai-nilai kearifan lokal daerahnya.

Kondisi-kondisi tersebut sesuai dengan teori pergeseran bahasa menyangkut masalah mobilitas penutur sebagai akibat dari perpindahan penutur atau para penutur itu dapat menyebabkan terjadinya pergeseran bahasa, seperti penutur yang tadinya menggunakan bahasa ibu kemudian menjadi tidak menggunakan lagi (Chaer dan Leonie Agustine, 2014:134). Menurutnya, pergeseran bahasa juga bisa terjadi dalam masyarakat tutur menyangkut masalah penggunaan bahasa oleh seorang penutur atau sekelompok penutur yang bisa terjadi sebagai akibat perpindahan dari satu masyarakat tutur ke masyarakat tutr lain. Sejalan dengan pendapat pakar, Sambas (2016:30) menyatakan bahwa hubungan yang berlangsung antar-satuan atau komponen secara teratur dalam kelompok sosial menercakup struktur, organisasi, nilai-nilai sosial, dan aspirasi hidup serta cara mencapainya. Artinya, keteraturan dan kelestarian suatu tuturan (bahasa daerah) dalam suatu masyarakat mutlak dijaga dengan baik untuk menjaga keberlangsungannya.

\section{METODE}

Metode yang digunakan adalah metode deskriptif dengan pendekatan kualitatif. Terkait metode tersebut, Denzim dan Lincoln (dalam Ahmadi, 2014: 14) menyatakan bahwa kualitatif menekankan pada proses dan makna yang tidak diuji atau diukur dengan setepat-tepatnya dalam istilah-istilah kuantitas, jumlah, intensitas, atau frekuensi. Sementara itu, Bogdan dan Tailor (dalam Ahmadi, 2014: 15) menjelaskan metode kualitatif sebagai prosedur penelitian yang dihasilkan secara deskriptif. Artinya bahwa ucapan atau tulisan dan perilaku yang 
dapat diamati dari orang-orang (subjek) itu sendiri. Dengan kata lain jenis penelitian ini menghasilkan temuan-temuan yang tidak diperoleh oleh alat-alat prosedur statistik atau alat-alat kuantifikasi lainnya (Strauss dalam Ahmadi, 2014: $15)$.

Sejalan dengan pendapat pakar-pakar di atas, Abdullah (2015: 74) menjelaskan bahwa ruang lingkup penelitian kualitatif sama dengan besaran ruang lingkup ilmu sosial yang meliputi, sosiologi, politik, ekonomi, hukum, administrasi, komunikasi, antropologi, dan lain-lain. Menurut pandangannya bahwa objek yang diamati oleh ilmu-ilmu sosial memiliki variasi gejala majemuk dan ini pula yang menjadikan fenomena unik bagi ilmu-ilmu sosial serta diakui sebagai karakteristik yang mempunyai keunggulan lebih dibandingkan dengan ilmu-ilmu alam yang lebih banyak menyajikan peristiwa-peristiwa monoton dan bersifat rutin. Oleh karena itu, kajian terhadap objek-objek perilaku sosial memiliki keunikan tersendiri yang tidak didapatkan pada ilmu-ilmu alam pada umumnya. Dengan demikian, perilaku yang mempunyai gejala yang tampak dapat diamati, dapat dikonsepkan, dan dapat diukur sebagai variabel-variabel yang muncul di dalam masyarakat yang merupakan wilayah penelitian kualitatif.

Pendekatan kualitatif dimaksudkan untuk menjelaskan perolehan data-data penelitian dari lapangan. Hal ini juga sesuai dengan pernyataan Ahmadi (2014: 13) bahwa pendekatan kualitatif menemukan apa yang sedang terjadi dan kemudian membuktikan apa yang telah ditemukan. Teknik pengambilan data dalam penelitian ini melalui observasi dan wawancara. Observasi dan wawancara dilakukan peneliti untuk melihat dan mengetahui penggunaan bahasa Galik dalam masyarakat, baik di rumah, masyarakat, dan sekolah. Bagaimana masyarakat menempatkan bahasa daerah (Galik) dalam kehidupan sehari-hari. Sifat pertanyaan terbuka disesuaikan dengan kondisi di lapangan. Informan dalam penelitian dari berbagai unsur, yaitu Kepala Bidang Kebudayaan Kabupaten Sanggau, Camat Beduai, Ketua Adat Beduai, Kepala SMPN 01 Beduai, guruguru, pelatih, dan siswa-siswi SMPN 01 Beduai. Peneliti beranggapan bahwa informan-informan tersebut mewakili penutur bahasa Galik yang berada di Kecamatan Beduai dan Kabupaten Sanggau. Informasi-informasi yang terkumpul kemudian ditranskripsikan dengan seksama dan dikelompokkan sesuai dengan permasalahan penelitian. Terakhir, analisis data dan pembahasan merupakan langkah terakhir dari kegiatan penelitian ini. Pada tahap ini, ketelitian dan ketajaman peneliti sangat diperlukan dalam menafsirkan data-data yang diperoleh dari berbagai sumber sesuai dengan apa adanya.

\section{PEMBAHASAN}

\section{Tantangan Bahasa Dayak Galik}

Masyarakat Merantau ke Kota

Era-milenial merupakan era yang serba canggih dan masyarakat sangat bergantung pada perangkat teknologi. Masyarakat berlomba-lomba memiliki dan menguasai era-milenial dengan berbagai cara. Tantangan masyarakat Dayak Galik di era-milenial cukup berat. Era-milenial ini mengharuskan setiap orang berpacu cepat dengan perkembangan teknologi yang tidak terbendung keberadaannya. Teknologi berkembang pesat di seluruh pelosok dunia termasuk di Kalimantan 
Barat. Masyarakat memanfaatkan teknologi (internet) atau media sosial sebagai sarana komunikasi dan memperoleh informasi terkini. Saat ini, media sosial telah menjadi platform pelaporan dan sumber berita utama bagi masyarakat. Sumber informasi melalui media sosial atau medsos menjadi andalan utama masyarakat, mulai bangun tidur sampai mau tidur kembali, masyarakat tidak lepas dari informasi.

Sumber informasi yang cepat tentu mengharuskan masyarakat mengalami perubahan yang cepat pula. Perubahan tersebut dimaknai masyarakat bahwa semua harus berbeda termasuk gaya hidup dan status sosial. Untuk kepentingan gaya hidup dan status sosialnya, banyak orang meninggalkan tempat kelahirannya untuk memperbaiki taraf hidup demi perubahan status mereka. Masyarakat (Dayak Galik) juga melakukan hal sama untuk mencoba keberuntungan yang lebih baik. Upaya itu dilakukan dalam rangka menyesuaikan diri dengan eramilenial yang serba canggih dan konsumtif.

Upaya penyesuaian status tersebut tentu tidak bisa dipisahkan dengan alat komunikasi yang mereka gunakan. Interaksi komunikasi masyarakat Dayak Galik dengan penduduk tempatan, misalnya Kota Pontianak tidak bisa terhindarkan. Setiap etnis, pasti memiliki keinginan untuk mempertahankan etnisitasnya melalui bahasa. Bahasa Galik pun pasti ingin digunakan oleh penuturnya meskipun mereka berada di daerah rantau (kota). Begitu juga dengan masyarakat tempatan, mereka pasti akan mempertahankan bahasanya sebagai bahasa pengantar ketika mereka berkomunikasi dengan penutur yang berbeda. Bahasa menjadi alat yang ampuh dalam berinteraksi dan berkomunikasi dengan etnis yang berbeda. Untuk bekerja sama dengan orang lain (beda etnis), tentu harus dipilih bahasa yang bisa mempersatukan mereka, seperti bahasa Indonesia. Dalam hal ini, penduduk pendatang berusaha berdamai dengan kondisi yang seperti itu. Maksudnya, masyarakat berpenutur Galik harus berkomunikasi dengan bahasa yang digunakan oleh masyarakat mayoritas. Berdamai dengan kondisi inilah akan memberikan dampak positif dan negatif bagi keberlangsungan bahasa Galik. Dampak positif yang dimaksud bahwa penutur Galik bisa berinteraksi baik dengan masyarakat di Kota Pontianak dengan menggunakan bahasa Melayu Pontianak. Hal tersebut memberikan penilaian positif bagi masyarakat yang ada di Kota Pontianak. Namun, dampak negatif yang muncul dari situasi tersebut adalah berkurangnya frekuensi penggunaan bahasa Galik di lingkungan penutur Galik sendiri.

Berdamai tidak hanya pada tataran bahasa, masyarakat berpenutur Galik juga melakukan asimilasi perkawinan dengan penduduk tempatan. Misalnya, orang Galik menikah dengan orang Tionghoa, Melayu, Bugis, Jawa, dan suku lainnya. Asimilasi perkawinan ini mengharuskan pasangan tersebut membuat kesepakatan, terutama bahasa yang akan mereka gunakan. Kesepakatan yang diambil oleh keduanya biasanya bisa menguntungkan kedua belah pihak atau merugikan salah satunya. Namun, situasi tersebut bisa disiasati oleh pasangan itu dengan cara berkomunikasi dengan baik. Hal tersebut sejalan dengan pendapat pakar komunikasi, Suciati (2015: 137) yang menyatakan bahwa komunikasi yang berorientasi sosial adalah komunikasi yang relatif menekankan hubungan keharmonisan dan hubungan sosial yang menyenangkan dalam keluarga. Artinya, secara langsung atau tidak langsung anak diajari menghindari perselisihan dan 
menekan perasaannya agar bisa menghindari perdebatan dengan orang lain termasuk pilihan bahasa yang digunakan oleh anak di sebuah keluargas.

Keluarga merupakan tempat bagi sebagian besar dari kita untuk mempelajari komunikasi, bahkan bisa dikatakan tempat bagi sebagian besar dari kita untuk belajar bagaimana kita berpikir mengenai komunikasi. Gambaran ini sesuai dengan pernyataan Lestari dalam Suciati (2015:97) bahwa keluarga merupakan tempat yang penting bagi tumbuh kembang anak yaitu menyangkut perkembangan fisik, emosi, spritual, dan sosial.

Terkait hal tersebut, pemilihan bahasa anak penutur Galik pun ditentukan orang tua (keluarga) sebelum dikenalkan pada lingkungan yang lain. Masalah yang muncul adalah jika pasangan sebuah keluarga terbentuk dari dua etnis dengan tuturan yang berbeda. Tuturan yang berbeda tersebut menjadi permasalahan yang serius untuk keberlangsungan bahasa Galik. Anak-anak dari pasangan berpenutur beda pasti bingung untuk memilih bahasa yang akan mereka gunakan. Terlebih, jika kedua orang tuanya ingin menekankan bahasa yang mereka miliki sebagai identitas sukunya. Di sinilah, mereka (anak-anak) bingung untuk memilih salah satu bahasa yang digunakan oleh orang tua mereka. Dengan alasan bingung untuk memilih itulah, akhirnya generasi muda (penutur Galik) memilih bahasa yang mudah dimengerti dan dianggap lebih popular. Contohnya, bahasa Indonesia yang dianggap sebagai bahasa pemersatu di antaretnis yang ada. Selain itu, penutur Galik beranggapan bahwa bahasa Indonesia mudah dimengerti oleh semua kalangan.

Dampak dari asimilasi perkawinan terlihat dalam kehidupan masyarakat Dayak Galik. Bergesernya atau kurang diminatinya bahasa Galik oleh penuturnya merupakan kondisi yang mengkhawatirkan banyak pihak. Kekhawatiran tersebut bukannya tanpa dasar karena sebagian besar penutur Galik tidak lagi menggunakan bahasanya sebagai identitas bahasa mereka. Alasannya bermacammacam, yaitu bahasa Galik dianggap sudah kuno dan tidak modern lagi pada eramilenial ini. Semua sudah canggih dan bahasa yang lain bisa dipelajari dengan mudah dan cepat, misalnya bahasa Indonesia. Berkat perkembangan teknologi seperti android, internet, dan parabola, semua bisa diakses dengan cepat. Melalui teknologi yang serba canggih tersebut, setiap orang bisa mempelajari semuanya termasuk bahasa dengan cepat pula. Bahasa-bahasa yang digunakan oleh masyarakat khususnya kalangan remaja cukup memprihatinkan karena sudah tidak sesuai dengan aturannya. Mereka menggunakan bahasa yang dicampur, misalnya bahasa Galik dicampur dengan bahasa Indonesia, Indonesia dicampur dengan Inggris, dan Galik dicampur dengan Ribun.

Penjelasan tersebut memberi gambaran situasi kebahasaan penutur Galik di Kecamatan Beduai, Kabupaten Sanggau. Dampak yang ditimbulkan dari asimilasi perkawinan beda bahasa (budaya) terhadap bahasa Galik cukup memprihatinkan. Jika situasi seperti ini berlangsung terus dan tidak dicarikan solusi, seiring berjalannya waktu, bahasa Galik ini pun akan ditinggalkan penuturnya mengikuti zamannya. Hal tersebut sejalan dengan penelitian Grimes (2002: 6) yang menyatakan bahwa akibat pergeseran bahasa akan menimbulkan hilangnya bahasa ibu (daerah). Pergeseran yang dimaksud adalah penutur Galik yang memilih bahasa daerah lain atau bahasa Indonesia di dalam masyarakat. Mereka 
Tuah Talino

Tahun XIII Volume 13 Nomor 2 Edisi 6 Desember 2019

ISSN 0216-079X E-ISSN 2685-3043

Balai Bahasa Kalimantan Barat

lebih memilih bahasa Indonesia daripada bahasa Galik ketika mereka berinteraksi. Pada bagian lain, Grimes menyebutkan gejala-gejala kepunahan bahasa diawali dengan penurunan secara drastis jumlah penuturnya dan mengakibatkan, hilangnya aspek budaya, bidang-bidang yang dibahas dengan bahasa yang hampir punah makin berkurang, kaum muda tidak lagi menggunakan bahasa ibunya, usaha-usaha untuk mempertahankan identitas etnis tanpa menggunakan bahasa ibu, contoh-contoh dialek dari bahasa yang terancam punah, penutur terakhir tidak menguasai bahasanya dengan baik, dan bahasa kreol akan terbentuk apabila penutur bahasa-bahasa yang berbeda bergabung.

Pergeseran bahasa Galik sudah berlangsung beberapa tahun terakhir. Berdasarkan hasil observasi, sosialisasi, dan revitalisasi bahasa Galik di Kecamatan Beduai, Kabupaten Sanggau oleh Badan Bahasa beberapa waktu lalu, diperoleh bahwa sebagian besar masyarakat tidak menggunakan bahasa Galik sebagai bahasa komunikasi di lingkungan mereka. Mereka lebih tertarik bahasa lain yang ada di lingkungannya, misalnya bahasa Melayu dan Indonesia yang dianggap memiliki prestise tinggi dalam masyarakat. Keterpurukan itu didukung oleh lemahnya penggunaan bahasa Galik di lingkungan keluarga dan masyarakat. Idealnya, orang tua membiasakan penggunaan bahasa Galik dilingkungan keluarga agar anak-anak terbiasa mendengar bahasa daerahnya.

Hasil wawancara dengan pemuka masyarakat penutur Galik, yaitu Kepala Adat dan guru yang mengajar di SDN 02 dan SMPN 01 Kecamatan Beduai, mereka jarang menggunakan bahasa ibu (daerah) sebagai alat komunikasi di antara mereka walaupun mereka berasal dari satu suku yang sama. Penjelasan pemuka masyarakat tersebut mengejutkan banyak pihak karena anak-anak sudah tidak mau lagi menggunakan bahasa Galik. Dengan situasi seperti ini, para orang tua dan pemuka adat tidak memaksakan penggunaan bahasa Galik di lingkungannya kepada generasi muda karena mereka pun tidak mau menggunakan lagi.

Para orang tua berpendapat bahwa anak-anak mereka tidak mau menggunakan bahasa daerahnya sendiri. Alasannya, bahasa Galik tidak praktis digunakan di dalam masyarakat. Oleh karena itu, orang tua mereka tidak menekankan untuk menggunakan bahasa Galik menjadi bahasa pengantar di masyarakat. Lemahnya aturan penggunaan bahasa Galik di lingkungan mereka membuat masyarakat pada umumnya menggunakan bahasa yang dicampurcampur. Bahasa campuran ini digunakan di setiap ranah kehidupan (keluarga, masyarakat, dan sekolah). Para orang tua tidak memusingkan lagi bahasa apa yang digunakan di dalam keluarga mereka. Kebebasan penggunaan bahasa tersebut menghasilkan pemakaian bahasa yang cukup bervariasi di lingkungan keluarga dan masyarakat. Percampuran bahasa terjadi antara bahasa Galik dan bahasa lain seperti bahasa Indonesia, Melayu, bahasa daerah lain, dan asing, hal ini terjadi di Desa Kesmorego, Kecamatan Beduai, Kabupaten Sanggau.

Situasi kebahasaan yang demikian disebabkan perkembangan zaman yang semakin pesat sehingga setiap orang melakukan langkah-langkah untuk mengimbanginya. Langkah yang dilakukan diantaranya meningkatkan kemampuan berbahasa lain yang dianggap memiliki nilai jual tinggi di masyarakat. Dengan menguasai bahasa Indonesia dengan baik, berpeluang 
Tuah Talino

Tahun XIII Volume 13 Nomor 2 Edisi 6 Desember 2019

ISSN 0216-079X E-ISSN 2685-3043

Balai Bahasa Kalimantan Barat

mendapatkan pekerjaan dan status sosial yang lebih baik. Misalnya, ketika seseorang menguasai bahasa Indonesia, Melayu, dan asing lebih baik dari yang lain, orang itu yang akan mendapat posisi yang lebih baik di dalam masyarakat. Dengan menguasai beberapa bahasa termasuk daerah, seseorang meyakini bisa menguasai lingkungan dan zamannya. Dampak dari kondisi tersebut, adalah terkesampingkannya bahasa ibu (daerah) yang dimiliki khususnya, bahasa Dayak Galik. Jadi, tantangan bagi bahasa Galik adalah bagaimana mengeksiskan bahasa tersebut pada era-milenial yang canggih tanpa menghilangkan identitas etnis di dalamnya.

\section{Generasi Cendekia}

Pada zaman milenial ini, orang berlomba-lomba meningkatkan kompetensi dan profesionalisme dalam segala hal. Kompetensi dan profesionalisme itu diperlukan untuk bisa bersaing dan berkompetisi dengan orang lain yang lebih maju. Hal tersebut hanya bisa diperoleh melalui jalur pendidikan dan pelatihan. Tidak dipungkiri bahwa pendidikan menentukan langkah atau arah kehidupan seseorang pada masa selanjutnya. Pendidikan yang memadai dan ditambah dengan keterampilan yang cukup akan memberi kesempatan kepada seseorang untuk diterima di dalam masyarakat. Ada anggapan di dalam masyarakat bahwa orang yang memiliki pendidikan dan keterampilan yang cukup akan berperan aktif pada era-milenial.

Mobilitas kalangan muda untuk melanjutkan pendidikan ke jenjang yang lebih tinggi cukup besar ke kota. Hal tersebut sesuai dengan hasil penelitian Minza (2012:155) dalam Jurnal Studi Pemuda yang menyatakan bahwa cepatnya perpindahan kaum muda ke Pontianak dari daerah-daerah lain di Kalimantan Barat untuk menempuh pendidikan tinggi merupakan sebuah bentuk migrasi dari desa ke kota. Tingginya mobilitas kaum muda ke kota memiliki dampak yang cukup besar terhadap perkembangan daerah.

Dampak positif yang dimaksud adalah semakin terdidiknya generasi muda yang menimba ilmu di kota akan memberikan sumbang pemikiran terhadap kemajuan daerahnya. Pandangan-pandangan maju dan profesional mereka akan mewarnai langkah ke depannya. Hal tersebut sebagai bentuk implementasi ilmu pengetahuan yang mereka peroleh selama mengenyam pendidikan di kota besar. Selain itu, perubahan sikap dan interaksi juga terlihat ketika mereka kembali ke daerah masing-masing.

Perubahan sikap berbahasa pun bisa diamati ketika mereka (kaum cendekia) kembali ke daerah masing-masing, yaitu melalui cara mereka berkomunikasi di dalam masyarakat. Di lain pihak, para cendekia ini mempunyai pengetahuan lebih dari pada masyarakat yang tidak mengenyam pendidikan ke kota. Namun, perubahan berbahasa atau berinteraksi mereka tidak sejalan dengan pendidikan yang mereka sandang. Mereka tidak peduli lagi dengan bahasa yang telah membesarkannya yaitu bahasa ibunya (daerah). Maksudnya, berbekal pendidikan yang tinggi, timbul kesadaran dan keinganan untuk mengembangkan bahasa Galik seperti bahasa daerah lain yang sudah berkembang. Tidak sedikit kelompok cendekia yang mencoba menghidupkan dan mengembangkan aset daerah (bahasa ibu) setelah mereka kembali ke kampung halamannya. Sebaliknya, penutur bahasa 
Tuah Talino

Tahun XIII Volume 13 Nomor 2 Edisi 6 Desember 2019

ISSN 0216-079X E-ISSN 2685-3043

Balai Bahasa Kalimantan Barat

Galik kelompok cendekia ini ada kecenderungan menggunakan bahasa yang dicampur dengan bahasa lain mewarnai keseharian mereka. Bergesernya cara berbahasa tersebut, sangat disayangkan berbagai pihak karena dianggap tidak peduli terhadap identitas mereka. Terkait identitas, Ma'aruf (2016: 37) mengatakan bahwa "...kehilangan identitas oleh pemiliknya, mereka merasa ini hal yang biasa-biasa saja. Buktinya, pemiliknya tidak merasa khawatir dan tidak ada usaha untuk menjaga identitasnya sendiri. Padahal, pemiliknya sudah menyadari bahwa bahasa daerah yang mencerminkan identitasnya berada dalam kondisi yang sangat memprihatinkan."

Bentuk melunturnya identitas daerah di kalangan cendekia itu terutama dilihat dari bahasa yang digunakan. Mereka beralih pada bahasa-bahasa yang dominan dan terkenal dalam lingkungannya, misalnya bahasa Indonesia. Bahasa Indonesia menjadi bahasa utama di setiap ranah kehidupan mereka, baik lingkungan keluarga, masyarakat, dan sekolah. Bahasa tersebut menjadi ikon dan alat komunikasi mereka khususnya kalangan cendekia karena bahasa tersebut dianggap pemersatu setiap lapisan masyarakat. Hasil pengamatan dan wawancara peneliti dalam kegiatan sosialisasi dan revitalisasi bahasa Galik di Kecamatan Beduai, Kabupaten Sanggau tahun 2018 diperoleh simpulan bahwa secara umum kelompok cendekia lebih senang memilih bahasa Indonesia sebagai alat komunikasi diantara mereka. Pemilihan bahasa Indonesia sebagai alat komunikasi bukan pilihan yang salah. Namun, sikap lebih memilih bahasa Indonesia daripada bahasa daerahnya (Galik) di lingkungannya merupakan sikap memperihatinkan karena akan mematikan aset daerahnya sendiri.

Penggunaan bahasa Indonesia dapat diamati ketika para cendekia berbicara di forum formal dan non-formal. Misalnya, bahasa Indonesia menjadi dominan penggunaannya oleh mereka (para cendekia) ketika berada di lingkungan sekolah, desa, kelurahan, kecamatan, dan dinas. Begitu juga dengan masyarakat pada umumnya, mereka lebih memilih menggunakan bahasa Indonesia ketika mereka berbicara di forum formal dan non-formal. Sementara, penggunaan bahasa Indonesia di ranah tidak formal terjadi di lingkungan keluarga dan masyarakat. Sebenarnya, lingkungan keluarga sangat dominan dalam penerapan penggunaan bahasa. Hal tersebut sejalan dengan pepatah pada umumnya bahwa seorang anak belajar berkomunikasi pertama kali di lingkungan keluarganya. Artinya, bahwa bahasa yang melekat pada diri seseorang termasuk kalangan cendekia adalah bahasa orang tuanya.

Selain bahasa Indonesia yang berkibar di daerah, bahasa Melayu Sanggau juga menjadi primadona bagi masyarakat terutama kalangan muda (cendekia) penutur Galik. Bagi kalangan muda (kelompok cendekia), bahasa Melayu dianggap bahasa yang mudah dipahami dan merakyat. Artinya, bahasa ini dikenal dan dimengerti oleh setiap kalangan. Menurut kelompok ini, pilihan berbahasa mereka sangat wajar jatuh pada bahasa Melayu karena masyarakat juga memilih bahasa tersebut ketika berkomunikasi. Alasan bahwa bahasa Melayu mudah dimengerti dan dipahami oleh setiap kalangan menyebabkan bahasa Galik semakin tersingkirkan. Anggapan banyak kalangan bahwa bahasa Melayu merupakan satu dari sekian bahasa yang memiliki prestise tinggi dalam masyarakat Dayak Galik benar adanya. Anggapan tersebut sesuai dengan hasil 
Tuah Talino

Tahun XIII Volume 13 Nomor 2 Edisi 6 Desember 2019

ISSN 0216-079X E-ISSN 2685-3043

Balai Bahasa Kalimantan Barat

wawancara peneliti dengan guru di SMPN 01 Beduai, Kecamatan Beduai, Kabupaten Sanggau yang menyatakan bahwa bahasa Melayu menjadi pilihan kedua setelah bahasa Indonesia.

Kepopuleran penggunaan bahasa Melayu hampir menyamai bahasa Indonesia di kalangan terpelajar (cendekia). Pernyataan yang sama juga diutarakan oleh pemuka masyarakat, Bapak Donatus dan sekaligus pengajar di SDN 02 Beduai, Kecamatan Beduai, Kabupaten Sanggau. Menurut mereka (cendekia), bahasa Melayu bisa menjadi bahasa pengantar kedua setelah bahasa Indonesia. Kelebihan bahasa Melayu adalah mudah dipahami oleh setiap suku yang ada di Kecamatan Beduai dibandingkan dengan bahasa Galik (bahasa ibu mereka). Dengan kondisi tersebut, kaum terpelajar memiliki alasan untuk beralih dari bahasa daerahnya ke bahasa Melayu yang lebih berprestise.

Pilihan bahasa lainnya dari kelompok cendekia ini, yaitu bahasa Ribun, dan Jawa. Pilihan bahasa tersebut dipengaruhi oleh faktor geografis dan sejarah. Faktor geografi karena letak wilayah penutur bahasa Galik ini satu kabupaten dengan penutur bahasa Ribun. Sementara itu, pemilihan bahasa Jawa di lingkungan penutur Galik karena adanya program transmigrasi yang dilakukan pemerintah. Berdasarkan beberapa sumber, di antaranya, dari Ketua Forum Perbatasan Kalimantan Barat, Abelnus, mengatakan bahwa Dinas Tenaga Kerja dan Transmigrasi Provinsi Kalimantan Barat menyatakan bahwa ada dua kabupaten, yaitu Sanggau dan Sintang yang menjadi tujuan transmigrasi. Lokasi penempatannya di Kecamatan Kembayan dan sekitarnya termasuk Kecamatan Beduai http://pontianak.tribunnews.com/2017/03/03/abelnus-sambas-belummasuk-lokasi-transmigrasi-di-kalbar . Hal tersebut sejalan dengan program pemerintah sejak tahun 2016--2019 telah menargetkan pembangunan 500 unit hunian transmigrasi dengan konsep satuan pemukiman pemugaran (SP pugar) di perbatasan Kabupaten Sanggau, Kalimantan Barat dengan Serawak, Malaysia. http://rri.co.id/pontianak/post/berita/449568/daerah/pemerintah_bangun_500_huni an_transmigrasi_di_perbatasan_sanggaumalaysia.html.

Program pemerintah terkait dengan penyebaran penduduk di Kabupaten Sanggau tersebut otomatis akan memengaruhi interaksi komunikasi berbahasa antara pendatang dan penduduk aslinya. Saling memengaruhi akan terjadi dalam bahasa mereka. Intensitas pertemuan dan pergaulan yang tinggi akan memengaruhi mereka ketika berkomunikasi. Dalam kondisi seperti inilah, perubahan dan pergeseran suatu bahasa khususnya bahasa Galik terhadap bahasa yang lain akan terjadi pula. Peristiwa seperti ini biasanya terjadi pada setiap penutur. Hal tersebut sejalan dengan pandangan Fasold dalam Suandi (2014: 98) yang menyatakan bahwa pergeseran dan pemertahanan bahasa merupakan hasil dari proses pemilihan bahasa dalam jangka waktu yang sangat panjang. Pergeseran bahasa menunjukkan adanya suatu bahasa yang benar-benar ditinggalkan oleh komunitas penuturnya. Hal ini berarti bahwa ketika pergeseran bahasa terjadi, anggota suatu komunitas bahasa secara kolektif lebih memilih menggunakan bahasa baru daripada bahasa lama yang secara tradisional biasa dipakai. Pergeseran bahasa umumnya mengacu pada proses penggantian satu bahasa dengan bahasa lain dalam repertoire linguistik suatu masyarakat (Ibrahim dalam Suandi, 2014: 98). 
Tuah Talino

Tahun XIII Volume 13 Nomor 2 Edisi 6 Desember 2019

ISSN 0216-079X E-ISSN 2685-3043

Balai Bahasa Kalimantan Barat

Tantangan bagi penutur Galik yang masuk kategori cendekia ini adalah memperkuat keberadaan bahasa Galik di tengah masuknya bahasa daerah dan asing ke wilayahnya. Selain itu, program transmigrasi yang dicanangkan pemerintah pusat dan daerah pun memberikan tantangan bagi kaum cendekia, baik mempertahankan bahasa mereka maupun memperoleh kesetaraan setatus sosial yang sama dengan etnis yang lain. Oleh karena itu, keputusan yang cerdas dan bijak patut dilakukan oleh para cendekia.

\section{Harapan Bahasa Dayak Galik}

Gambaran di atas jelas bahwa tantangan yang dihadapi oleh bahasa Dayak Galik tidak kecil. Semakin berkembangnya suatu wilayah, dibutuhkan kearifan para penentu kebijakan dalam segala hal termasuk pengaturan regulasi atau penggunaan bahasa di dalam masyarakat itu sendiri. Selain itu, peran serta orang tua, anak, dunia pendidikan (guru dan peserta didik), dan masyarakat umum sangat diperlukan. Penggunaan bahasa daerah akan lemah jika tidak diikuti oleh peraturan daerah yang mengatur tentang kewajiban penggunaan bahasa daerah di lingkungannya. Hal tersebut ditujukan kepada semua lapisan masyarakat agar efeknya meluas. Contoh, penerapan dan keharusan menggunakan bahasa ibu di lingkungan keluarga mutlak dilakukan agar bahasa Galik terjaga kelestariannya. Para tua memiliki peran penting dalam menanamkan kebanggaan kepada anakanak mereka menggunakan bahasa daerah yang dimiliki. Pembiasaan tersebut bisa dilakukan pada situasi santai, misalnya saat makan bersama, menonton televisi, dan berbincang di sela waktu senggang. Jika dilakukan secara terus-menerus, hasilnya bisa dirasakan dalam kurun waktu tertentu.

Sikap berbahasa masyarakat Galik seharusnya bisa menempatkan bahasanya dengan baik. Upaya pelestarian bahasa Galik bisa dilakukan dengan berbagai cara di antaranya, memanfaatkan kemajuan teknologi canggih pada era-milenial ini. Pemanfaatan teknologi canggih itu, misalnya, alat musik dan media massa (televisi, radio, koran, dan medsos) untuk penyebarluasan bahasa Galik (daerah) yang mereka miliki kepada masyarakat umum. Dokumentasi bahasa dan sastra yang ada sangat diperlukan karena hal tersebut bentuk pelestarian aset daerah. Upaya untuk menjaga keberlangsungan dan pembinaan bahasa Galik, sebagai identitas etnis dan aset daerah, diperlukan kerjasama antara penutur (masyarakat Dayak Galik) dan pemerintah terkait. Masyarakat berpenutur Galik tidak perlu mengubah atau gengsi menggunakan bahasa daerah sebagai lambang identitas dirinya setelah kembali kampung halamannya. Melalui merekalah, bahasa tersebut semakin eksis keberadaanya dengan pengetahuan yang diperoleh dari rantau.

Pengetahuan masyarakat dan kaum terpelajar yang semakin tinggi dapat dipergunakan untuk kemajuan daerahnya, termasuk mempertahankan bahasa daerahnya. Pengetahuan dan kompetensi yang dimiliki masyarakat dan kaum terpelajar, diharapkan dapat membantu mengembangkan penggunaan bahasa Galik dengan lebih efektif, baik di lingkungannya maupun masyarakat luas. Penggunaan bahasa Galik bisa diaplikasikan di lingkungan masyarakat dan sekolah. Pencanangan di sekolah bisa dilakukan melalui kewajiban menggunakan bahasa daerah sehari dalam seminggu. Hal tersebut hanya bisa terjadi jika ada campur-tangan pemegang kebijakan, misalnya kepala dinas dan lembaga terkait, 
misalnya sekolah, kepala adat, dan orang tua. Kebijakan ini akan memberi dampak cukup besar terhadap kelestarian bahasa Galik karena ada keharusan menggunakannya di lingkungan tertentu. Ancangan ini sudah dilakukan oleh Pemerintah Kabupaten Sanggau melalui Kepala Bidang Kebudayaan. Kebijakan itu mewajibkan penggunaan bahasa Galik selam satu hari dalam satu pekan di lingkungan SMPN 01 Beduai, Kecamatan Beduai, Kabupaten Sanggau. Keputusan ini memberikan angin segar terhadap pelestarian bahasa Galik, khususnya, dan bahasa daerah yang lain (Melayu, Jawa, Ribun, dan Indonesia) yang ada di Kecamatan Beduai. Ancangan tersebut, berpeluang tinggi terhadap pelestarian dan pembinaan suatu bahasa di daerah. Harapan yang diinginkan tentu eksistensi bahasa Galik semakin terlihat.

Upaya tersebut bisa diikuti oleh kalangan terpelajar lainnya (kelompok cendekia) di lingkungannya. Misalnya, pencangan sehari menggunakan bahasa Galik di lingkungan kerja (kelurahan, kecamatan, dinas, dan kantor bupati). Tidak hanya di lingkungan pemerintah, masyarakat umum juga bisa ikut serta dalam pencanangan berbahasa daerah tersebut, misalnya, kepala suku, temenggung, dan ketua adat memegang peran penting dalam keberlangsungan bahasa daerah yang mereka miliki. Peran cendekia dan pemuka masyarakat tersebut akan mempercepat integritas dan menjaga identitas yang dimiliki daerah dengan baik. Begitu juga dengan keberadaan bahasa sebagai kearifsan lokal yang ada di daerah perlu dilestarikan karena aset daerah termasuk aset nasional.

\section{PENUTUP}

Dari hasil pembahasan dapat disimpulkan bahwa tantangan bahasa Galik pada era-milenial, berupa mobilitas masyarakat yang cukup tinggi untuk mencari pekerjaan dan generasi muda yang melanjutkan pendidikan ke kota-kota besar. Tingginya jumlah masyarakat dan generasi muda yang bermigrasi ke kota-kota besar berpotensi melemahkan identitasnya sebagai putra daerah. Identitas yang dimaksud adalah bahasa dan budaya yang dimiliki tidak digunakan lagi ketika mereka berada di kota. Melemahnya penggunaan bahasa Galik khususnya bagi penuturnya karena lingkungannya berbeda bahasa. Pergeseran tersebut juga disebabkan oleh faktor asimilasi dalam perkawinan. Asimilasi tersebut berdampak cukup signifikan terhadap penggunaan bahasa pada anak-anak hasil pernikahan beda etnis atau bahasa. Orang tua tidak bisa menekan anak-anak mereka untuk memilih bahasa kedua orang tua mereka. Selain itu, kurangnya intensitas orang tua untuk membiasakan berbahasa daerah di lingkungan keluarga memperburuk kondisi penggunaan bahasa di setiap daerah, khususnya pada penutur Galik.

Tingginya mobilitas generasi muda (terpelajar) yang melanjutkan pendidikan di kota-kota besar juga memiliki dampak negatif setelah mereka kembali ke daerah asalnya. Satu diantara dampak negatif yang diperlihatkan kelompok cendekia ini adalah perubahan sikap berbahasa mereka. Hasil pengamatan dan wawancara menunjukkan bahwa kalangan terpelajar mengalami perubahan atau pergeseran ketika berbahasa, dari bahasa daerah ke bahasa lain. Mereka tidak lagi menggunakan bahasa Galik ketika berada di lingkungan keluarga, masyarakat, dan situasi tertentu. Kalangan terpelajar ini lebih memilih bahasa Indonesia dan Melayu ketika mereka berinteraksi, baik dengan sesama 
Tuah Talino

Tahun XIII Volume 13 Nomor 2 Edisi 6 Desember 2019

ISSN 0216-079X E-ISSN 2685-3043

Balai Bahasa Kalimantan Barat

penutur Galik maupun dengan penutur bahasa daerah lain. Alasan yang mencuat adalah bahasa Indonesia merupakan bahasa pemersatu antar-etnis dan bahasa Melayu mudah dipahami. Adanya anggapan bahwa bahasa-bahasa tersebut memiliki prestise yang tinggi di dalam masyarakat. Selain bahasa Indonesia dan Melayu, bahasa Jawa, Ribun, dan asing menjadi pilihan masyarakat dan kaum cendekia Dayak Galik. Hal tersebut sangat disayangkan, mengingat slogan nasional yang sedang digalakkan oleh Badan Bahasa; "mengutamakan bahasa Indonesia, melestarikan bahasa daerah, dan menguasai bahasa asing" kurang berpihak terhadap masyarakat penutur Galik.

\section{DAFTAR PUSTAKA}

Abdullah, Ma'ruf. (2015). Metodologi Penelitian Kualitatif (Untuk Ekonomi, Manajemen, Komunikasi, dan Ilmu Sosial Lainnya). Yogyakarta: Aswaja Pressindo.

Ahmadi, Rulam. (2014). Metodologi Penelitian Kualitaif. Yogyakarta: Ar-Ruzz Media.

Chaer Abdul dan Leonie Agustina. (2014). Sosiolinguistik Perkenalan Awal. Jakarta: Rineka Cipta.

Florentina

$\mathrm{dkk}$

.(2016).

http://jurnal.untan.ac.id/index.php/jpdpb/article/dowload/10400/10050.

(diakses 16 Desember 2018).

Grimes, Barbara F. (2002). "Kecenderungan Bahasa untuk Hidup atau Mati secara Global (Global Language Viability): Sebab, Gejala, dan Pemulihan untuk Bahasa-Bahasa yang Terancam Punah". Diterbitkan PELBBA 15 Pertemuan Linguistik Pusat Kajian Bahasa dan Budaya Atma Jaya: Kelima Belas. Jakarta: Kanisius.

http://pontianak.tribunnews.com/2017/03/03/abelnus-sambas-belum-masuklokasi-transmigrasi-di-kalbar (diakses 3 Januari 2019).

http://rri.co.id/pontianak/post/berita/449568/daerah/pemerintah_bangun_500_huni an_transmigrasi_di_perbatasan_sanggaumalaysia.html (diakses 3 Januari 2019).

https://www.kominfo.go.id/content/detail/8566/mengenal-generasimillennial/0/sorotan_media (diakses 3 Januari 2019).

Ma'aruf, Salmiati. (2016). "Bahasa Daerah: Identitas yang Memudar" dalam Bahasa, Sastra, \& Identitas: Eksistensi Bahasa Indonesia dan Daerah. Maluku: Kantor Bahasa Maluku.

Martina. (2018a). "Bahasa Pengungkap Budaya Dayak Galik" dalam Jurnal Sirok Bastra Volume 6, No. 2 Tahun 2018. Kementerian Pendidikan dan Kebudayaan. Kantor Bahasa Provinsi Bangka Belitung.

---. (2018b) “Upaya Revitalisasi Bahasa Galik Menguatkan Pengetahuan Generasi Muda akan Nilai Kearifan Lokal dalam Proseding Internasional. Kementerian Pendidikan dan Kebudayaan. Balai Bahasa Jawa Barat.

Minza, Wenty Marina. (2012). "Migran Muda dan Transisi dari Pendidikan ke Dunia Kerja di Pontianak, Kalimantan Barat" dalam Jurnal Studi Pemuda, Vol.1, No. 2 September 2012. 
Tuah Talino

Tahun XIII Volume 13 Nomor 2 Edisi 6 Desember 2019

ISSN 0216-079X E-ISSN 2685-3043

Balai Bahasa Kalimantan Barat

Sambas, Syukriadi. (2016). Antropolinguistik Komunikasi. Bandung: Pustaka Setia.

Suandi, I Nengah. (2014). Sosioinguistik. Yogyakarta: Graha Ilmu.

Suciati. (2015). Komunikasi Interpersonal sebuah Tinjauan Psikologis dan Perspektif Islam. Yogyakarta: Buku Litera Yogyakarta.

Sumarsono. (2013). Sosiolinguistik. Yogyakarta: Pustaka Pelajar. 